\title{
Acute administration of high dose trimetazidine inhibits pentylenetetrazol-induced seizures in rats
}

\section{Yüksek doz akut trimetazidin uygullaması sıçanlarda pentilentetrazol ile indüklenen nöbetleri önler}

\author{
Serkan GURGUL ${ }^{1}$, Nilgun ERTEN², Serdar Savas GUL ${ }^{3}$, Nurten ERDAL ${ }^{4}$, Coșar UZUN ${ }^{4}$, Volkan \\ SOLMAZ ${ }^{5}$, Oytun ERBAS ${ }^{6}$
}

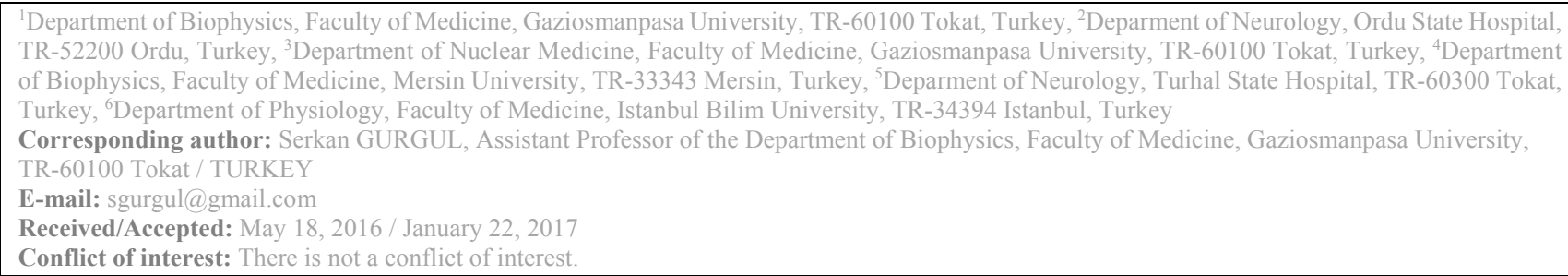

\section{SUMMARY}

Objective: Resistant epilepsy is widely seen in clinical settings manipulate the researchers to pursuit novel anti-epileptic treatments. Although trimetazidine (TMZ) is commonly used in the treatment of angina and ischemic diseases, it is considered that the drug may be beneficial in the treatment of epileptic seizures and convulsions. We aimed to evaluate electrophysiologically the protective effects of high dose acute TMZ on epileptic seizures and convulsions in a rat model of epilepsy induced by pentilentetrazol (PTZ).

Method: Forty-eight male Sprague-Dawley rats were used for the EEG evaluation (Group-A; n=24) and behavioral assessment (Group-B; n=24). Grup-A1 and Grup-B1 were determined as control group and given no medication. 35 $\mathrm{mg} / \mathrm{kg}$ (Group-A2, -A3 and -A4) and $70 \mathrm{mg} / \mathrm{kg}$ (Group-B2, -B3 and -B4) of PTZ were administered intraperitoneally (ip.) so as to generate seizures and convulsions. Group-A2 and Group-B2 were treated with saline. $40 \mathrm{mg} / \mathrm{kg}$ (Grup-A3 and Grup-B3) and $80 \mathrm{mg} / \mathrm{kg}$ of TMZ (Group-A4 and Group-B4) were administered to the treatment groups by ip. Brain malondialdehyde (MDA) levels, spike-percentage values, Racine's Convulsion Scale (RCS) scores and "first myoclonic jerk (FMJ)" latencies of each rat were determined.

Results: Brain MDA levels, spike-percentage values, RCS scores, and FMJ latencies of Group-A2 and Group-B2 were significantly increased compared to those of the control's (Grup-A1 and Grup-B1) (P<0.05 for all comparisons). However, in TMZ treated groups (Group-A3 and -A4; Group-B3 and -B4) the elevated values of these parameters were found to be significantly decreased $(\mathrm{P}<0.05$ for all comparisons).

Conclusions: This study has demonstrated that the high dose acute TMZ administration may prevent PTZ-induced seizures and convulsions in rats. Furthermore, it can be also said that TMZ has a neuroprotective effects on oxidative stress associated with PTZ. Therefore, it may be considered for use with therapeutic purposes of TMZ in resistant epilepsy patients in the future.

Keywords: Electroencephalography (EEG), Epilepsy, Malondialdehyde, Pentylenetetrazol, Rat, Trimetazidine. 
Yöntem: 48 adet erkek Sprague-Dawley cinsi sıçan EEG (Group-A; n=24) ve davranıș analizlerinde (Group-B; n=24) kullanıldı. Grup-A1 ve Grup-B1 kontrol grubu olarak belirlendi ve ilaç verilmedi. 35 mg/kg (Group-A2, -A3 ve -A4) ve 70 mg/kg PTZ (Group-B2, -B3 ve -B4), nöbet ve konvülsiyon oluşturmak amacıyla, intraperitoneal olarak (ip.) uygulandı. Grup-A2 ve Grup-B2'ye serum fizyolojik verildi. Tedavi gruplarına 40 mg/kg (Grup-A3 ve Grup-B3) ve 80 mg/kg TMZ (Grup-A4 ve Grup-B4) ip. yöntemi ile uygulandı. Sıçanlara ait beyin malondialdehit (MDA) seviyeleri, tepe noktası yüzde değerleri, "Racine Konvülsiyon Skalası (RCS)" skorları ve "ilk miyoklonik kasılma latansları (FMJ)" değerlendirildi.

Bulgular: Grup-A2 ve Grup-B2'ye ait beyin MDA seviyeleri, tepe noktası yüzde değerleri, RCS skorları ve FMJ latanslarının kontrol gruplarına (Grup-A1 and Grup-B1) göre anlamlı derecede arttığı saptandı $(\mathrm{P}<0.05)$. Bununla birlikte, TMZ ile tedavi edilen gruplarda (Grup-A3 and -A4; Grup-B3 and -B4) FMJ latansları haricinde bu parametrelerde gözlenen artışların önemli ölçüde azaldığı saptandı $(\mathrm{P}<0.05)$.

Sonuç: Bu çalışma ile yüksek doz akut TMZ uygulamasının sıçanlarda PTZ ile indüklenen nöbetleri ve konvülsiyonları önleyebileceği gösterilmiştir. Ayrıca, TMZ'nin PTZ ile ilişkili oksidatif stres üzerinde nöroprotektif bir etkisi olduğu da söylenebilir. $\mathrm{Bu}$ nedenlerle, gelecekte dirençli epilepsi hastalarında TMZ'nin terapötik amaçlarla kullanılması düşünülebilir.

Anahtar sözcükler: Elektroensefalografi (EEG), Epilepsi, Malondialdehit, Pentilentetrazol, Sıçan, Trimetazidin.

\section{INTRODUCTION}

Epilepsy is a complex and the most common multifactorial neurological disorder (incidence 2953 cases per 100.000 per year; prevalence $5-8$ cases per 1000; lifetime prevalence 3-5\%) for which the pathogenesis is still unclear despite the numerous previous studies on this issue ${ }^{1-4}$. The societal costs of epilepsy are fairly high. Based on a survey in 1995, the annual cost for epileptic patients in the USA is estimated to be approximately $\$ 12.5$ billion $^{5}$. New developed drugs were increased the cost \$2000-3000 per year per patient, from $\$ 400$ 1300 for previous generation of first line medications. Surgery is now an important option for the increasing number of patients with epilepsy and even larger numbers of patients are undergoing pre-surgical assessments. Owing to these additional factors, the cost of epilepsy has increased $^{6}$. Despite to the available treatment methods, resistance to anti-epileptic drugs affects $20 \%$ to $40 \%$ of patients with epilepsy ${ }^{7,8}$. Current treatment options for these patients are limited and this limitation causes an increase in morbidity and mortality. The economic burden of drug-resistant epilepsy is substantial and is responsible from $80 \%$ of the money spent for epileptic patients ${ }^{7,8,9}$. This situation creates an importance for the urgency of identifying novel drugs for epilepsy treatment.

Trimetazidine (TMZ) is a piperazine-derived lipophilic agent came into focus with use in angina treatment and for ischemic events ${ }^{10}$. The drug exerts anti-ischemic effect without inducing hemodynamic changes ${ }^{11}$. TMZ inhibits mitochondrial 3-ketoacyl-coa-tiolase enzyme, leading to discontinuation of $\beta$-oxidation of fatty acids. In turn, use of glucose increases. The blockage of membrane lipid peroxidation reduces the release of inorganic phosphate and phosphocreatine, as well as the production of free oxygen radicals. Another possible effect of TMZ is the prevention of intracellular calcium accumulation by controlling the membrane ion gradients, taking the intracellular $\mathrm{pH}$ under control $^{11,12}$. It also prevents intracellular swelling by decreasing the intracellular potassium loss and inhibition of $\mathrm{Na} / \mathrm{Ca}$ pump ${ }^{13}$. In summary, the drug maintains ATP stores against ischemia-induced intracellular acidosis and prevents the production of free oxygen radicals ${ }^{14}$. It has been suggested that TMZ exerts anti-excitotoxic effects through $\alpha$ amino-3-hydroxy-5-methyl-4-isoxazolepropionic acid (AMPA)/kainite receptor antagonism ${ }^{15}$.

TMZ has been shown in experimental animal models to be beneficial against ischemia in several organs including the heart and the brain, peripheral nerves, inner ear, kidney, lung, bowel, liver, and stomach $^{15-22}$. Despite the clearly-defined antiischemic effects of the TMZ, there are a limited number of studies in the literature on the potential effects of TMZ in epileptic seizures or convulsions $^{10,23}$.

In the present study, based on the anti-oxidant as well as anti-excitotoxic effects of TMZ representing a candidate drug for the treatment of drug-resistant epilepsy, we aimed to evaluate if high dose TMZ has an acute effects on penthylenetetrazol (PTZ)-induced seizures and convulsions by using EEG recordings and behavioral assessment in rats. For the biochemical assessment, an oxidative biomarker malondialdehyde (MDA), was also evaluated in rats' brain. To the best of our knowledge, no previous study has evaluated the anti-convulsant and anti-oxidant efficacy of acute administration of high dose trimetazidine in PTZ-induced seizure in rats. 


\section{MATERIAL and METHODS}

All experiments and protocols described in the present study were performed in accordance with the Guide for the Care and Use of Laboratory Animals, as adopted by National Institutes of Health (U.S.) and also approved by the Medical Faculty Experimentation Ethics Committee of Gaziosmanpasa University.

Forty-eight male (24 of them for EEG recording and 24 of them are for behavioral studies) SpragueDawley rats, weighing 200-250 g each, were used in this study. The rats were kept under a $12 \mathrm{~h}$ light/dark cycle (light from 07.00 to 19.00 ), in quiet rooms, with $22-24^{\circ} \mathrm{C}$ ambient temperature and provided free access to standard rat nutrients and purified drinking water ad libitum.

\section{Drugs}

Pentylenetetrazol (PTZ; Sigma-Aldrich, Interlab Inc., Istanbul, Turkey) and trimetazidine (TMZ; 1 [2,3,4-trimethoxybenzyl]

piperazinedihydrochloride; Vastare ${ }^{\circledR} \mathrm{MR}$ ) were dissolved in $0.9 \%$ saline. Drug solutions were prepared freshly in the morning.

\section{Experimental Procedures}

Forty-eight rats were randomly and equally divided in two groups: Group A for EEG recordings and Group B for behavioral assessment. For the EEG recordings, rats were deeply anesthetized using 80 $\mathrm{mg} / \mathrm{kg}$ ketamine $\mathrm{HCl}$ (Ketalar, Pfizer Pharmaceuticals, Istanbul, Turkey) and $4 \mathrm{mg} / \mathrm{kg}$ xylazine (Rompun, Bayer AG., Istanbul, Turkey) mixture intraperitoneally (ip.). Small hole was opened with a drill under stereotaxically following the anesthesia. The electrodes (polyamide-coated stainless steel wires, $0.1 \mathrm{~mm}$ diameter and electrical resistance $<1 \Omega / 10 \mathrm{~mm}$ ) were implanted on dura over left frontal cortex $(2.0 \mathrm{~mm}$ lateral to the midline, $1.5 \mathrm{~mm}$ anterior to the bregma ${ }^{24}$ ) and the reference electrode was implanted over cerebellum $(1.5 \mathrm{~mm}$ posterior to the lambda, on midline $\left.{ }^{24}\right)$. The electrodes were fixed by using dental acrylic following the implantation ${ }^{25,26}$.

$35 \mathrm{mg} / \mathrm{kg} \mathrm{PTZ}$ is ideal for observing changes in EEG spikes but does not consistently produce observable behavioral changes, while $70 \mathrm{mg} / \mathrm{kg}$ PTZ consistently produced observable behavioral changes but EEG readings have small signal to noise ratio to see differences in drug concentrations ${ }^{24}$.

After 12 days from electrode fixation, 24 rats were divided randomly into 4 groups (6 rats per group): Group-A1, -A2, -A3, and -A4.Group-A1 was defined as control and given no medication. GroupA2 was carried out with $1 \mathrm{ml} / \mathrm{kg}$ saline, while the
Group-A3 and Group-A4 were administered 40 $\mathrm{mg} / \mathrm{kg} T M Z$ and $80 \mathrm{mg} / \mathrm{kg} T M Z$, respectively. All administrations were done ip. The drugs were administered 30 minutes prior to PTZ injection. All groups, except Group-A1, were received $35 \mathrm{mg} / \mathrm{kg}$ $P T Z$ and EEG was recorded. EEG recordings were taken in awake rats in a special container after 5 minutes from PTZ administration ${ }^{26}$. The EEG recordings were taken in 60 minutes $^{26}$, the signals were amplified 10.000 times and also filtered with a range of 1-60 Hz. EEG records were taken by using the BIOPAC MP150 Data Acquisition System (Biopac System Inc., Santa Barbara, USA) and spike percentage (We defined "spike percentage" as a reproducible way of quantifying epileptiform activity is to quantify the percentage of 1-second bins with at least one spike-wave ${ }^{27}$ ) was evaluated. Two clinical neurophysiologists scored the EEG data for spike percentage. We also affirmed the electrode location histologically following euthanasia.

For the behavioral assessment, the groups were rearranged with the remaining 24 rats (Group-B) and these rats were then divided into 4 groups (6 rats per group): Group-B1, -B2, -B3, and -B4. Group-B1 was defined as control and given no medication. Group-B2 was carried out with $1 \mathrm{ml} / \mathrm{kg}$ saline, while the Group-B3 and Group-B4 were administered $40 \mathrm{mg} / \mathrm{kg} \mathrm{TMZ}$ and $80 \mathrm{mg} / \mathrm{kg} T M Z$, respectively. The drugs were administered 30 minutes prior to $70 \mathrm{mg} / \mathrm{kg} \mathrm{PTZ} \mathrm{injection.} \mathrm{All}$ administrations were done ip. Racine's Convulsion Scale (RCS) and onset times of "first myoclonic jerk" (FMJ) was used to evaluate the seizures (for only $70 \mathrm{mg} / \mathrm{kg}$ PTZ) as follows: $0=$ no convulsion; $1=$ twitching of vibrassae and pinnae; $2=$ motor arrest with more pronounced twitching; $3=$ motor arrest with generalized myclonic jerks (this time was recorded for evaluating FMJ onset time); $4=$ tonic-clonic seizure while the animal remained on its feed; $5=$ tonic-clonic seizure with loss of the righting reflex; $6=$ lethal seizure ${ }^{25,26}$. The onset times were recorded as seconds. Almost all animals showing tonic generalized extension were died. The observation period for PTZ-induced seizures was limited with 30 minutes duration ${ }^{28,29}$. After this duration, the animals were euthanized.

\section{Evaluation of lipid peroxidation}

Lipid peroxidation was determined in plasma samples by measuring MDA levels as thiobarbituric acid reactive substances (TBARS). Briefly, trichloroacetic acid and TBARS reagent were added to the plasma samples, then mixed and incubated at $100{ }^{\circ} \mathrm{C}$ for $60 \mathrm{~min}$. After cooling on ice, the samples were centrifuged at $3000 \mathrm{rpm}$ for $20 \mathrm{~min}$ and the absorbance of the supernatant was 
read at $535 \mathrm{~nm}$. Tetraethoxypropane was used for calibration and brain MDA levels were expressed as $\mathrm{nM}$.

\section{Statistical analysis}

Results were expressed as a mean \pm standard error of mean (SEM). Data analyses were performed by utilizing SPSS version 15.0 for Windows. ShapiroWilk test is used to determine if a population of values has a normal distribution. The spike percentage, MDA, RCS score, and FMJ on set time were evaluated by one-way analysis of variance (ANOVA) followed by the Bonferonni or KruskalWallis post-hoc tests, as applicable. The value of $P<0.05$ was accepted as statistically significant.

\section{RESULTS}

\section{Evaluation of EEG records}

The mean \pm SEM values of spike percentage of all groups are listed in Table 1 and EEG recordings of all groups are shown in Fig. 1. The highest spike percentage values were detected in $\mathrm{PTZ}+$ saline group. The mean percentage values were significantly lower in $\mathrm{PTZ}+40 \mathrm{mg} / \mathrm{kg}$ and $\mathrm{PTZ}+80$ $\mathrm{mg} / \mathrm{kg}$ TMZ groups than that of the PTZ+saline group $(P<0.0001$, respectively). The average of spike percentage in $\mathrm{PTZ}+80 \mathrm{mg} / \mathrm{kg}$ TMZ group was found significantly lower than that of the PTZ+40 mg/kg group $(P<0.0001)$.

Table 1. Spike percentage values by the groups.

\begin{tabular}{|l|c|}
\hline Groups & Spike Percentage (\%) \\
\hline Control & 0 \\
\hline PTZ $(35 \mathrm{mg} / \mathrm{kg})+1 \mathrm{ml} / \mathrm{kg}$ saline & $76.3 \pm 9.2$ \\
\hline PTZ $(35 \mathrm{mg} / \mathrm{kg})+40 \mathrm{mg} / \mathrm{kg} \mathrm{TMZ}$ & $42.5 \pm 6.1^{\mathrm{a}^{\dagger}}$ \\
\hline PTZ $(35 \mathrm{mg} / \mathrm{kg})+80 \mathrm{mg} / \mathrm{kg} \mathrm{TMZ}$ & $16.2 \pm 5.4^{\mathrm{a} \dagger, \mathrm{b}^{\dagger}}$ \\
\hline
\end{tabular}

PTZ: Pentylenetetrazol, TMZ: Trimetazidine. Each group consists of six rats. The results are expressed as mean \pm SEM of the values. Statistical analyses were performed by one-way analysis of variance (ANOVA). ${ }^{\mathrm{a} C o m p a r e d ~ t o ~ P T Z ~}+$ saline, ${ }^{\mathrm{b}} \mathrm{Compared}$ to PTZ $+40 \mathrm{mg} / \mathrm{kg}$ TMZ. ${ }^{\dagger} P<0.0001$. The cases, where statistically significant differences were found, are given in the table.
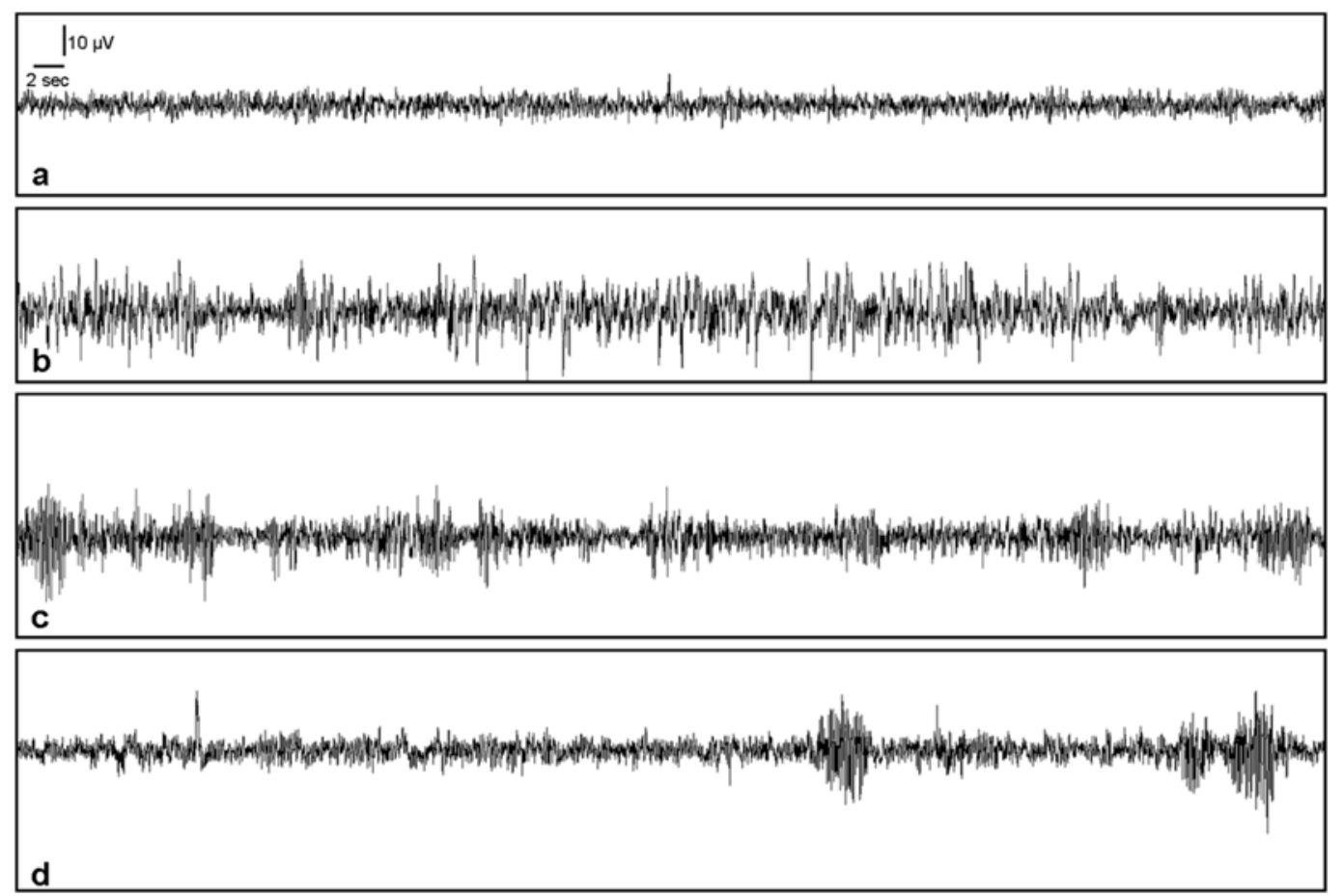

Fig. 1.EEG recordings (a) Normal, (b) PTZ + saline, (c) PTZ + $40 \mathrm{mg} / \mathrm{kg}$ TMZ group, (c): PTZ + $80 \mathrm{mg} / \mathrm{kg}$ TMZ group. 


\section{Evaluation of the seizures}

The mean \pm SEM values of RCS scores and FMJ onset time of all groups are listed in Table 2. The highest RCS score and the lowest FMJ latency (excluding the control group) were detected in $\mathrm{PTZ}+$ saline group. The decreases in both $\mathrm{PTZ}+40$ $\mathrm{mg} / \mathrm{kg} \mathrm{TMZ}$ and the PTZ $+80 \mathrm{mg} / \mathrm{kg}$ TMZ groups were found statistically significant in comparison to that of the PTZ+saline group with regard to the RCS scores $(P<0.001, P<0.0001$; respectively $)$.
Similarly, FMJ latencies were markedly higher in PTZ+40 $\mathrm{mg} / \mathrm{kg} \mathrm{TMZ}$ and the PTZ+80 $\mathrm{mg} / \mathrm{kg}$ TMZ groups than that of the $\mathrm{PTZ}+$ saline group $(P<0.001, P<0.0001$; respectively). Moreover, the decrease in RCS score and the increase in FMJ latency values in $\mathrm{PTZ}+80 \mathrm{mg} / \mathrm{kg} \mathrm{TMZ}$ group were found significant when compared to those of the $\mathrm{PTZ}+40 \mathrm{mg} / \mathrm{kg}$ TMZ group $(P<0.01, P<0.001$; respectively).

Table 2. Comparison of groups in terms of convulsion stage (RCS) scores and first myoclonic jerk (FMJ) latencies.

\begin{tabular}{|l|c|c|}
\hline Groups & $\begin{array}{c}\text { Convulsion Stage (RCS } \\
\text { scores) }\end{array}$ & $\begin{array}{c}\text { FMJ onset times } \\
\text { (s) }\end{array}$ \\
\hline Control & 0 & 0 \\
\hline PTZ $(70 \mathrm{mg} / \mathrm{kg})+1 \mathrm{ml} / \mathrm{kg}$ saline & $5.83 \pm 0.1$ & $69.3 \pm 10.49$ \\
\hline PTZ $(70 \mathrm{mg} / \mathrm{kg})+40 \mathrm{mg} / \mathrm{kg} \mathrm{TMZ}$ & $3.66 \pm 0.5^{\mathrm{a} \ddagger}$ & $198.1 \pm 17.06^{\mathrm{a} \ddagger}$ \\
\hline PTZ $(70 \mathrm{mg} / \mathrm{kg})+80 \mathrm{mg} / \mathrm{kg} \mathrm{TMZ}$ & $2.83 \pm 0.3^{\mathrm{a} \ddagger} \mathrm{b}^{*}$ & $244.83 \pm 15.62^{2^{\natural} ;, b \ddagger}$ \\
\hline
\end{tabular}

RCS: Racine's convulsion scale, FMJ: First myoclonic jerk, PTZ: Pentylenetetrazol, TMZ: Trimetazidine. Each group consists of six rats. The results are expressed as mean \pm SEM of the values. Statistical analyses were performed by one-way analysis of variance (ANOVA). ${ }^{\mathrm{a} C o m p a r e d ~ t o ~ P T Z ~+~ s a l i n e, ~}{ }^{\mathrm{b} C o m p a r e d ~ t o ~ P T Z ~}+40 \mathrm{mg} / \mathrm{kg}$ TMZ. ${ }^{\dagger} P<0.0001,{ }^{\sharp} P<0.001,{ }^{*} P<0.01$. The cases, where statistically significant differences were found, are given in the table.

\section{Evaluation of brain lipid peroxidation (MDA)}

The mean \pm SEM values of brain MDA levels of all groups are listed in Table 3.Brain MDA levels in $\mathrm{PTZ}+$ saline group were found significantly higher than that of the control group $(P<0.01)$. On the other hand, MDA levels were significantly decreased in $\mathrm{PTZ}+40 \mathrm{mg} / \mathrm{kg}$ and $\mathrm{PTZ}+80 \mathrm{mg} / \mathrm{kg}$ TMZ groups compared to that of the PTZ+saline group ( $P<0.05$; respectively). Moreover, levels in PTZ+80 mg/kg TMZ group was markedly lower than that of thePTZ $+40 \mathrm{mg} / \mathrm{kg}$ TMZ group $(P<0.05)$.

Table 3. Brain malondialdehyde (MDA) levels by the groups.

\begin{tabular}{|l|c|}
\hline Groups & $\begin{array}{c}\text { Brain MDA levels } \\
\text { (nM) }\end{array}$ \\
\hline Control & $68.2 \pm 4.6$ \\
\hline PTZ $(70 \mathrm{mg} / \mathrm{kg})+1 \mathrm{ml} / \mathrm{kg} \mathrm{saline}$ & $135.4 \pm 8.3^{\mathrm{a}^{*}}$ \\
\hline PTZ $(70 \mathrm{mg} / \mathrm{kg})+40 \mathrm{mg} / \mathrm{kg} \mathrm{TMZ}$ & $112.6 \pm 5.5^{\mathrm{b}^{\prime \prime}}$ \\
\hline PTZ $(70 \mathrm{mg} / \mathrm{kg})+80 \mathrm{mg} / \mathrm{kg} \mathrm{TMZ}$ & $103.5 \pm 6.8^{\mathrm{b}^{\prime \prime}, \mathrm{c}^{\prime \prime}}$ \\
\hline
\end{tabular}

MDA: Malondialdehyde, PTZ: Pentylenetetrazol, TMZ: Trimetazidine. Each group consists of six rats. The results are expressed as

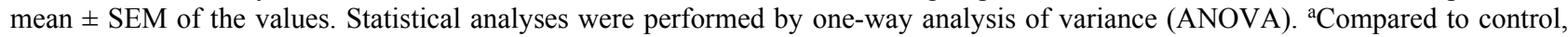
${ }^{b}$ Compared to PTZ + saline, ${ }^{\mathrm{c}}$ Compared to PTZ $+40 \mathrm{mg} / \mathrm{kg}$ TMZ. ${ }^{*} P<0.01, " P<0.05$. The cases, where statistically significant differences were found, are given in the table.

\section{DISCUSSION}

There are many different mechanism considered to have a role in epileptogenesis. With a general definition, epileptic seizures are caused by the imbalance between excitatory and inhibitory stimuli in an epileptic focus ${ }^{30}$.

Epilepsy may be caused by the intracellular calcium accumulation induced by increased synaptic transmission of AMPA/kainatereceptor of glutamate. Oxidative stress may also contribute to the pathophysiology of epilepsy. Moreover, free oxygen radicals are among the factors associated with resistant epilepsy patients ${ }^{30-33}$.

It is well known that energy consumption increases in the cell during and after the epileptic seizures. Acceleration of energy consumption is associated 
with lipid peroxidation, resulting in increase in free oxygen radicals ${ }^{34-36}$. Free oxygen radicals exacerbate the existing clinical symptoms of epilepsy which is manifested as resistant epilepsy cases. MDA is a lipid peroxidation product indicating the oxidative stress ${ }^{37,38}$. Seizures have been shown to increase the oxidative stress in experimental epilepsy models. Repeated and prolonged seizures have been considered to lead an uncontrolled increase in free oxygen radicals and an increase in oxidative stress, triggering the neuronal death and apoptosis ${ }^{39}$. Previous experimental studies have found that TMZ exerts a protective effect on cells by decreasing the production of free oxygen radicals ${ }^{40-44}$.

Accordingly, in the present study, we found significantly higher MDA levels in $\mathrm{PTZ}+$ saline group than in control group, indicating PTZinduced oxidative damage in rat's brain $(P<0.01)$. In acute conditions, PTZ-induced elevated MDA levels in brain have been reported in various studies such as Uyanikgil et al. ${ }^{26}$ and Cevik et al ${ }^{45}$. In these studies, $70 \mathrm{mg} / \mathrm{kg}$ of PTZ was used to induce convulsions in rats, as in our study, and findings of the present study are in good accordance with the results of the above-mentioned studies. On the other hand, the MDA levels in PTZ $+40 \mathrm{mg} / \mathrm{kg}$ $\mathrm{TMZ}$ and $\mathrm{PTZ}+80 \mathrm{mg} / \mathrm{kg} \mathrm{TMZ}$ groups were markedly reduced compared to that of the PTZ+saline group $(P<0.05$; Table 3$)$. Moreover, the levels in PTZ $+80 \mathrm{mg} / \mathrm{kg} \mathrm{TMZ}$ was found to be significantly decreased compared to that of the $\mathrm{PTZ}+40 \mathrm{mg} / \mathrm{kg}$ TMZ group $(P<0.05$; Table 3$)$. Thus, TMZ was concluded to decrease the oxidative stress dose-dependently in PTZ-induced epilepsy model in rats and it can be suggested that the TMZ has a protective effect on oxidative damage associated with PTZ in brain. Although the protective effects of TMZ on oxidative tissue damage have been shown in various experimental studies $^{40-44}$, there are only a few studies investigating the efficacy of TMZ on this issue in brain $^{10,46}$.

Results of the present study show that the highest RCS score and the lowest FMJ latency (excluding the control group) were detected in PTZ + saline group (Table 2). The decrease in RCS score and the increase in FMJ latency were found significant in groups treated with TMZ compared to that of the PTZ + saline group $(P<0.001$ vs. PTZ $+40 \mathrm{mg} / \mathrm{kg}$ TMZ and $P<0.0001$ vs. PTZ $+80 \mathrm{mg} / \mathrm{kg} \mathrm{TMZ)}$ (Table 2). Spike percentage values were significantly lower in TMZ-treated groups $(P<0.0001$; Table 1). Moreover, changes in RCS, FMJ, and spike percentage which were seen in groups treated with TMZ were increased as the dosage increases (Table 1 and 2). As a result, it can be suggested that the TMZ was found to have anticonvulsant activity which is dose-dependent.

Results of the present study are in accordance with similar previous studies ${ }^{10,23}$. In the study by Jain et al. ${ }^{10}$, the anti-convulsant activity of TMZ has been studied in an electroshock model of epilepsy with investigating the possible involvement of calcium channel blockage and using nimodipine and phenytoin. The authors have concluded that TMZ may have anti-convulsant activity through modulation of calcium channels. In another study by Jain et al. ${ }^{23}$, the effect of TMZ on PTZ-induced epilepsy has been assessed by oxidative stress markers and seizure scores. In contrast to our study, TMZ has been administered for 5 weeks in that study. Chronic effects of TMZ have been evaluated by measurement of brain MDA and reduced glutathione levels. Similar to our study, those authors have also reported a dose-dependent anticonvulsant effect for $\mathrm{TMZ}^{23}$. Our study differs from that study, because we used TMZ in higher doses and evaluated the acute effects of the drug and found more anti-convulsant effect when the drug was used in higher doses.

It is possible that the anti-convulsant effect of TMZ is caused at least partly by antagonizing the AMPA and kainite receptors against glutamatergic excitotoxicity which is responsible from epileptogenesis and cell loss ${ }^{15}$. Another possible anti-epileptic action of mechanism is decreasing the free oxygen radicals, which effect is considered to be associated with inhibition of mitochondrial 3ketoacyl-coa-tiolase enzyme and decreased fatty acid $\beta$-oxidation, as well as increased pyruvate dehydrogenase activity by $37 \%$ (the rate-limiting enzyme in glucose oxidation) ${ }^{11}$. Moreover, TMZ maintains intracellular potassium, sodium and calcium balance, preventing intracellular acidosis $^{13}$.Thus, by this way; TMZ may show effectiveness against treatment-resistant epilepsy cases.

Our results may prove that the high dose TMZ have an inhibitory effect on seizures and shows an anticonvulsant effect on PTZ-induced epilepsy in rats. These effects increases the dosage increases. It can be also said that TMZ have a protective effect on oxidative damage associated with PTZ in brain. To the best of our knowledge, this is the first paper that investigated the acute effects of high dose TMZ on PTZ-induced seizures and convulsions. The most important limitation of our study is the lack of the assessment of the evaluation of other oxidant or anti-oxidant biomarkers such as superoxide dismutase, nitrotryosine, etc. TMZ is a reliable and 
well-tolerated drug which is in use by clinician for many years. Certainly, because limited data exists, TMZ cannot be introduced as an effective antiepileptic yet. However, it can be suggested that TMZ may be considered as an alternative therapy in the future for drug-resistant epilepsy patients and that this study will guide future studies on the potential anti-convulsant effects of the drug.

\section{Acknowledgments:}

\section{REFERENCES}

1. Jacobs MP, Fischbach GD, Davis MR, Dichter MA, Dingledine R, et al. Future directions for epilepsy research. Neurology 2001; 57: 1536-42.

2. Scharfman HE, Schwarcz R. Neuromodulation of seizures, epileptogenesis and epilepsy. In. Engel J, Pedley TA (Eds). Epilepsy a comprehensive textbook. $2^{\text {nd }}$ ed. Philadelphia: Lippincott Williams \& Wilkins, 2008; pp 289-305.

3. Walker MC, Surges R, Fisher A. Mechanisms of antiepileptic drug action. In. Shorvon S, Perruca E, Engel J (Eds). The treatment of epilepsy. $3^{\text {rd }}$ ed. Oxford: Wiley-Blackwell, 2009; pp 91-108.

4. Tetto A, Manzoni P, Millul A, Beghi E, Garattini L, Tartara A, Avanzini G; Osservatorio Regionale per l'Epilessia (OREp). The costs of epilepsy in Italy: a prospective cost-of-illness study in referral patients with disease of different severity. Epilepsy Res 2002; 48: 207-16.

5. Begley CE, Famulari M, Annegers JF, Lairson DR, Reynolds TF, Coan S, Dubinsky S, Newmark ME, Leibson C, So EL, Rocca WA. The cost of epilepsy in the United States: an estimate from populationbased clinical and survey data. Epilepsia 2000; 41: 342-51.

6. Begley CE, Lairson DR, Reynolds TF, Coan S. Early treatment cost in epilepsy and how it varies with seizure type and frequency. Epilepsy Res 2001; 47: 205-15.

7. Kwan P, Schachter SC, Brodie MJ. Drugresistant epilepsy. N Engl J Med 2011; 365: 919-26.

8. Sisodiya S. Drug resistance in epilepsy: not futile, but complex? Lancet Neurol 2003; 2: 331.

9. Engel J. Overview of surgical treatment for epilepsy. In. Shorvon S, Perruca E, Engel J
Funding: Authors declare no support from any organization for this work.

Ethical approval: Ethical approval received from the Medical Faculty Experimentation Ethics Committee of Gaziosmanpasa University.

Declaration of authorship: SG, VS, and $\mathrm{OE}$ contributed to study design and also performed EEG recordings and behavioral assessment. OE also performed the measurement of brain MDA levels and the statistical analysis. All authors participated in data interpretation and review and writing of the manuscript.

(Eds). The treatment of epilepsy. $3^{\text {rd }}$ ed. Oxford: Wiley-Blackwell, 2009; pp 743-56.

10. Jain S, Bharal N, Mediratta PK, Sharma KK. Trimetazidine exerts protection against increasing current electroshock seizure test in mice. Seizure 2010; 19: 300-2.

11. Kantor PF, Lucien A, Kozak R, Lopaschuk GD. The antianginal drug trimetazidine shifts cardiac energy metabolism from fatty acid oxidation to glucose oxidation by inhibiting mitochondrial long-chain 3ketoacyl coenzyme A thiolase. Circ Res 2000; 86: 580-8.

12. Belardinelli R. Trimetazidine and the contractile response of dysfunctional myocardium in ischaemic cardiomyopathy. Rev Port Cardiol 2002; 19: 35-9.

13. Gil-Loyzaga P, Hernández E, Carricondo F, Simón F, Poch-Broto J. Trimetazidine prevents cochlear lesions induced by intraperitoneal and perilymphatic administration of kainic acid. Brain Res 1999; 826: 95-103.

14. Aubert A, Bernard C, Clauser P, Harpey C, Vaudry $H$. The anti-ischemic drug, trimetazidine, prevents the deleterious effects of oxygen free-radicals on the internal ear. Ann Otolaryngol Chir Cervicofac 1990; 107: 28-35. (Abstract)

15. Dayanithi G, Desmadryl G, Travo C, Chabbert C, Sans A. Trimetazidine modulates AMPA/kainate receptors in rat vestibular ganglion neurons. Eur J Pharmacol 2007; 574: 8-14.

16. Tetik C, Ozden A, Calli N, Bilgihan A, Bostanci B, Yis O, Bayramoglu $\mathrm{H}$. Cytoprotective effect of trimetazidine on 60 minutes of intestinal ischemia-reperfusion injury in rats. Transpl Int 1999; 12: 108-12.

17. Settaf A, Morin D, Lamchouri F, Elimadi A, Cherrah Y, Tillement JP. Trimetazidine ameliorates the hepatic injury associated 
with ischemia-reperfusion in rats. Pharmacol Res 1999; 39: 211-6.

18. Inci I, Dutly A, Rousson V, Boehler A, Weder W. Trimetazidine protects the energy status after ischemia and reduces reperfusion injury in a rat single lung transplant model. J Thorac Cardiovasc Surg. 2001; 122: 1155-61.

19. Iqbal S, Baziany A, Hussain M, James S, Wright S, Hemmings S, Shuaib A, Rajput A. Trimatazidine as a potential neuroprotectant in transient global ischemia in gerbils: a behavioral and histological study. Brain Res 2002; 928: 1-7.

20. Chander V, Singh D, Chopra K. Attenuation of glycerol-induced acute renal failure in rats by trimetazidine and deferoxamine. Pharmacology 2003; 67: 418.

21. Abdel-Salam OM, El-Batran S. Pharmacological investigation of trimetazidine in models of inflammation, pain and gastric injury in rodents. Pharmacology 2005; 75: 122-32.

22. Serarslan Y, Bal R, Altug ME, Kontaş T, Keleş ON, Unal D, Unal B. Effects of trimetazidine on crush injury of the sciatic nerve in rats: a biochemical and stereological study. Brain Res 2009; 1247 : 11-20.

23. Jain $\mathrm{S}$, Bharal N, Khurana S, Mediratta PK, Sharma KK. Anticonvulsant and antioxidant actions of trimetazidine in pentylenetetrazole-induced kindling model in mice. Naunyn Schmiedebergs Arch Pharmacol 2011; 383: 385-92.

24. Paxinos G, WatsonC. The rat brain in stereotaxic coordinates. $3^{\text {rd }}$ ed. New York: Academic Press, 1991.

25. Erbaş O, Solmaz V, Aksoy D. Inhibitor effect of dexketoprofen in rat model of pentylenetetrazol-induced seizures. Neurol Res 2015; 37: 1096-101.

26. Uyanikgil Y, Özkeşkek K, Çavuşoğlu T, Solmaz V, Tümer MK, Erbas O. Positive effects of ceftriaxone on pentylenetetrazolinduced convulsion model in rats. Int $\mathrm{J}$ Neurosci 2014; 5: 1-18.

27. Aeby A, Poznanski N, Verheulpen D, Wetzburger C, Van Bogaert P. Levetiracetam efficacy in epileptic syndromeswith continuous spikes and wavess during slow sleep: experiencein 12 cases. Epilepsia 2005; 46: 1937-42.

28. Işeri SO, Sener G, Saglam B, Gedik N, Ercan F, Yegen BC. Oxytocin protects against sepsis-induced multiple organ damage: role of neutrophils. J Surg Res 2005; 126: 73-81.

29. Işeri SO, Sener G, Sağlam B, Gedik N, Ercan F, Yeğen BC. Oxytocin ameliorates oxidative colonic inflammation by a neutrophil-dependent mechanism. Peptides 2005: 26; 483-91.

30. Wilcox KS, West PJ, Dichter MA. Excitatory synaptic transmission. In. Engel J, Pedley TA (Eds). Epilepsy a comprehensive textbook. $2^{\text {nd }}$ ed. Philadelphia: Lippincott Williams \& Wilkins, 2008; 233-44.

31. Mathern GW, Wilson CL, Beck H. Hippocampal sclerosis. In. Engel J, Pedley TA, (Eds). Epilepsy a comprehensive textbook. $2^{\text {nd }}$ ed. Philadelphia: Lippincott Williams \& Wilkins, 2008; 121-36.

32. Devi PU, Manocha A, Vohora D. Seizures, antiepileptics, antioxidants and oxidative stress: an insight for researchers. Expert Opin Pharmacother 2008; 9: 3169-77.

33. Aguiar CC, Almeida AB, Araújo PV, de Abreu RN, Chaves EM, do Vale OC, Macêdo DS, Woods DJ, Fonteles MM, Vasconcelos SM. Oxidative stress and epilepsy: literature review. Oxid Med Cell Longev 2012; 2012: 795259.

34. Rola R, Swiader M, Czuczwar SJ. Electroconvulsions elevate the levels of lipid peroxidation products in mice. Pol $\mathrm{J}$ Pharmacol 2002; 54: 521-4.

35. Freitas RM. Investigation of oxidative stress involvement in hippocampus in epilepsy model induced by pilocarpine. Neuroscience Lett 2009; 462: 225-9.

36. Mareš J, Stopka P, Nohejlová K, Rokyta R. Oxidative stress induced by epileptic seizure and its attenuation by melatonin. Physiol Res 2013; 62: 67-74.

37. Deepa D, Jayakumari B, Thomas SV. Lipid peroxidation in women with epilepsy. Ann Indian Acad Neurol 2008; 11: 44-6.

38. Giera M, Lingeman H, Niessen WM. Recent advancements in the LC-and GCBased analysis of malondialdehyde (MDA): a brief overview. Chromatographia 2012; 75: 433-40.

39. Menon B, Ramalingam K, Kumar RV. Oxidative stres in patients with epilepsy is independent of antiepileptic drugs. Seizure 2012; 21: 780-4.

40. Marzilli M. Cardioprotective effects of trimetazidine: a review. Curr Med Res Opin 2003; 19: 661-72.

41. Lopaschuk GD, Barr R, Thomas PD, Dyck JR. Beneficial effects of trimetazidine in ex 
vivo working ischemic hearts are due to a stimulation of glucose oxidation secondary to inhibition of long-chain 3-ketoacyl coenzyme a thiolase. Circ Res 2003; 93: e33-7.

42. Singh D, Chopra K. Effect of trimetazidine on renal/reperfusion injury in rats. Pharmacol Res 2004; 50: 623-9.

43. Stanley WC. Myocardial energy metabolism during ischemia and the mechanisms of metabolic therapies. J Cardiovasc Pharmacol Ther 2004; 9: 31-45.

44. Castedo E, Segovia J, Escudero C, Olmedilla B, Granado F, Blas C, Guardiola JM, Millán I, Pulpón LA, Ugartea J.
Ischemia-reperfusion injury during experimental heart transplantation. Evaluation of trimetazidine's cytoprotective effect. Rev Esp Cardiol 2005: 58; 941-50 (Abstract).

45. Cevik B, Solmaz V, Aksoy D, Erbas O. Montelukast inhibits pentylenetetrazolinduced seizures in rats. Med Sci Monit 2015; 21: 869-74.

46. Suzer T, Coskun E, Demir S, Tahta K. Lipid peroxidation and glutathione levels after cortical injection of ferric chloride in rats: effect of trimetazidine and deferoxamine. Res Exp Med (Berl) 2000; 199: 223-9. 